2016, volume 5, issue 1

Erdoğan N. K., Altınırmak S., \& Karamaşa Ç. (2016). Comparison of multi criteria decision making (MCDM) methods with respect to performance of food firms listed in BIST. Copernican Journal of Finance \& Accounting, 5(1), 67-90. http://dx.doi.org/10.12775/CJFA.2016.004

\author{
Namik Kemal Erdoğan* \\ Anadolu University \\ Serpil Altinirmak ${ }^{* *}$ \\ Anadolu University \\ ÇaĞlar Karamaşa*** \\ Anadolu University
}

\title{
COMPARISON OF MULTI CRITERIA DECISION MAKING (MCDM) METHODS WITH RESPECT TO PERFORMANCE OF FOOD FIRMS LISTED IN BIST
}

Keywords: performance analysis, fuzzy ranking, TOPSIS, VIKOR, ELECTRE.

J E L Classification: C44, D81, L25.

Abstract: Analyzing firms' performance appropriately is core topic for decision makers working in financial sector under the conditions of imprecise and incomplete in-

Date of submission: May 22, 2016; date of acceptance: June 11, 2016.

* Contact information: nkerdoga@anadolu.edu.tr, Anadolu University, Faculty of Business, Department of Business Administration, Eskișehir/Turkey, phone: +902223350580 (2543).

** Contact information: saltinirmak@anadolu.edu.tr, Anadolu University, Eskişehir Vocational High School, Department of Finance, Eskişehir/Turkey, phone: +902223350580 (3138).

${ }^{* * *}$ Contact information: ckaramasa@anadolu.edu.tr, Anadolu University, Faculty of Business, Department of Business Administration, Eskișehir/Turkey, phone: +902223350580 (2554). 
formation. Purpose of this study is to assess firms' performance by taking financial ratios and financial experts' into the account. Therefore firstly weights of criteria and sub criteria related to financial ratios are obtained by using one of the fuzzy ranking methods namely Buckley's Column Geometric Mean Method. Following to this firms' final rankings are determined by means of TOPSIS, VIKOR and ELECTRE methods. Also ranking performance of these three methods is interpreted. According to this purpose financial ratios of twenty one food firms listed in BIST for four years period (2011-2014) are acquired and analyzed via these methods.

\section{INTRODUCTION}

Performance can be defined as efficiency in production or effectiveness in service. It is important to determine performance for firms' future condition. For that reason firms' performance should be measured. Neely et al. (1995) described the performance measurement as determination process of an activity's efficiency and effectiveness quantity (Yüreğir, Nakıboğlu 2007). Business executives view past decisions' results and make future investment decisions via financial performance measurement (Uyguntürk, Korkmaz 2012). Financial analysis which can be made by business executives, investors or credit firms is based on establishing relationships between items appeared in financial tables and commenting on this matter.

Financial ratios show relationships between financial table items mathematically (İç, Tekin,Pamukoğlu,Yıldırım 2015). Firms' strengths and weaknesses in terms of liquidity, growth and profitability can be revealed by financial ratios. Firms' year based changes and sector based performance comparisons are made with the aim of financial ratios (Uyguntürk, Korkmaz 2012). Financial ratios are chosen according to financial sector applications and finance literature. Basically financial ratios are classified into four group namely liquidity, financial structure, operating and profitability ratios. Firms' ability to pay short-term debts are determined via liquidity ratios. Currency ratio, acid test ratio and cash ratio are included in first group.

Financial structure ratios are used for determining the firm's outsourcing level. Leverage ratio denoted as total debts/total assets is considered in second group and it is possible to detect the percentage of assets subsidized by debts in case of assets selling (Dumanoğlu 2010). Operating ratios are used for exhibiting the efficient usage level of firms' assets. Asset turnover ratio denoted as net sales/total assets is considered in third group. Profitability ratios are used for measuring the earning power of firms' after activities fulfilled. Ratios namely 
net profit/total assets, net profit/capital and net profit/net sales are included in last group. Financial ratios used in this study are showed in Table 1.

Table 1. Financial Ratios

\begin{tabular}{|l|l|l|}
\hline \hline \multicolumn{1}{|c|}{ Financial Ratio Groups } & \multicolumn{1}{c|}{ Ratios } & \multicolumn{1}{c|}{ Explanation } \\
\hline \multirow{2}{*}{ Liquidity Ratios } & Currency Ratio & Current Assets/Short Term Debts \\
\cline { 2 - 3 } & Acid Test Ratio & $\begin{array}{l}\text { (Currents Assets- Stocks)/Short Term } \\
\text { Debts }\end{array}$ \\
\cline { 2 - 3 } & Cash Ratio & $\begin{array}{l}\text { (Liquid Assets + Securities)/ Short } \\
\text { Term Debts }\end{array}$ \\
\hline \multirow{2}{*}{ Financial Structure Ratios } & Leverage Ratio & Total Debts/Total Assets \\
\hline Operating Ratios & Asset Turnover Ratio & Net Sales/ Total Assets \\
\hline \multirow{2}{*}{ Profitability Ratios } & Net Profit/Total Assets & Net Profit/Total Assets \\
\cline { 2 - 4 } & Net Profit/Capital & Net Profit/Capital \\
\cline { 2 - 4 } & Net Profit/Net Sales & Net Profit/Net Sales \\
\hline \hline
\end{tabular}

S o u r c e : Tayyar, Akcanlı, Genç, Eram 2014.

Purpose of this study is to assess the properties of different Multi Criteria Decision Making (MCDM) methods and compare the results of them in terms of food firms' performance assessment by taking financial ratios and financial experts' view into the account. For this reason firstly local and global weights of criteria and sub-criteria related to financial ratios are obtained by using one of the fuzzy ranking methods namely Buckley's Column Geometric Mean Method. Following to this firms' final rankings are determined by means of TOPSIS, VIKOR and ELECTRE methods. Data sets for this study are financial ratios of twenty one food firms listed in BIST.

\section{LITERATURE REVIEW}

First financial analysis studies assessed via objective methods were made by Altman (1968). Altman acquired a discriminant function namely "z score model" by using financial ratios. Difficulties encountered in data entering and acquiring caused the method based on past years data to be developed. Usage of MCDM methods in measuring firms' financial performance is started to become widespread since 1980s (İç et al. 2015). 
Feng and Wang (2000) examined the performance of five airlines operated in Taiwan by means of TOPSIS and concluded the importance of financial indicators on the determination of airlines' performance. Yurdakul and İç (2003) examined the five large scale automobile firm in terms of financial structures and condition in the sector. Performance values for each year are compared with securities' year-end closing prices and results are found as consistent out of 2001. Mahmoodzadeh, Shahrabi, Pariazar and Zaeri (2007) determined the preference ranking of different projects by the means of fuzzy AHP, TOPSIS and traditional project evaluation methods such as net present value, rate of return, benefit-cost analysis and payback period. Wu, Tzeng and Chen (2009) proposed a fuzzy MCDM approach in order to evaluate banking performances based on Balanced Scorecard (BSC). For this purpose twenty three performance evaluation indexes were selected for banking performance of BSC by taking into the expert questionnaires. After that FAHP was employed to obtain relative weights of performance evaluation indexes and three MCDM methods (SAW, TOPSIS and VIKOR) were used to rank banking performances. Bülbül and Köse (2011) evaluated the financial performance of food sector on the basis of company and sector via TOPSIS and ELECTRE methods and found consistent results.

\section{RESEARCH METHODOLOGY}

AHP, developed by Saaty (1980), is a decision making mechanism composed of overall goal, criteria and sub criteria (if there are any), and alternatives. AHP methodology can be used for making decisions where choice, prioritization and forecasting are needed. AHP is based on structuring problem and eliciting properties through pairwise comparisons in decision making process (Ishizaka, Nemery 2013). By using AHP we can decouple problem into sub problems by evaluating subjectively manner that is transformed into numerical values and ranked on a numerical scale (Bhushan, Rai 2004).

Despite these specifications, AHP can not reflect human thinking style in inaccurate and subjective environment due to unbalanced scale of judgments, inability to adequately handle inherent uncertainty and imprecise pair-wise comparisons. For that reason fuzzy analytic hierarchy process (FAHP) extension of traditional AHP was developed to solve hierarchical fuzzy problems in interval judgment matrix (Kahraman, Cebeci, Ulukan 2003). 
Zadeh (1965) firstly proposed a mathematical theory namely fuzzy set in order to overcome vaguness and imprecise condition of human cognitive processes (Jie, Meng, Cheong 2006). Apart from classical set theory based on binary logic fuzzy set describe actual objects similar to human language (Huang, Ho 2013). A fuzzy set which is extension of crisp one allow partial belonging of element by membership function. Membership values of objects in a fuzzy set range from 0 (nonmembership) to 1 (complete membership). Values between these boundaries are called intermediate membership degrees and show degree to which an element belongs to a set (Ertuğrul, Karakaşoğlu 2009). Triangular and trapezoidal fuzzy numbers are mostly used in application fields. Triangular fuzzy numbers are used in this study due to computational easiness and representation usefulness.

Membership of triangular fuzzy number is defined by three real numbers expressed as $(\mathrm{l}, \mathrm{m}, \mathrm{u})$ indicating smallest possible value, the most promising value and the largest possible value respectively (Deng 1999). Fuzzy set theory allow respondents to explain semantic judgments subjectively (Huang, Ho 2013). For this reason Saaty's 9 point scale is transformed into the fuzzy ratio scale in terms of triangular fuzzy numbers.

Ranking fuzzy numbers in imprecise and vagueness environment is one of the essential problems in fuzzy optimization and fuzzy decision making. Fuzzy values are ranked according to the different specifications of fuzzy sets namely centre of attraction, area under the membership degree function and some intersection points (Chen, Hwang, Hwang 1992). Various fuzzy ranking methods can be used according to the complexity, sensitivity, easily interpretability of existing problem and type of fuzzy numbers (Kaptanoğlu, Özok 2006). Buckley (1985) developed a model to state decision maker's evaluation on alternatives with respect to each criterion by using triangular fuzzy numbers. Steps of Buckley's Column Geometric Mean method are given as follows:

1. Establishing hierarchical structure and comparing criteria or alternatives via fuzzy scale for constructing pair-wise comparison matrix shown as below:

$$
\widetilde{\mathrm{A}}^{\mathrm{k}}=\left[\begin{array}{cccc}
\widetilde{\mathrm{a}}_{11}^{\mathrm{k}} & \widetilde{\mathrm{a}}_{12}^{\mathrm{k}} & \ldots & \widetilde{\mathrm{a}}_{1 \mathrm{n}}^{\mathrm{k}} \\
\widetilde{\mathrm{a}}_{21}^{\mathrm{k}} & \widetilde{\mathrm{a}}_{22}^{\mathrm{k}} & \ldots & \widetilde{\mathrm{a}}_{2 \mathrm{n}}^{\mathrm{k}} \\
\ldots & \ldots & \ldots & \ldots \\
\widetilde{\mathrm{a}}_{\mathrm{m} 1}^{\mathrm{k}} & \widetilde{\mathrm{a}}_{\mathrm{m} 2}^{\mathrm{k}} & \ldots & \widetilde{\mathrm{a}}_{\mathrm{mn}}^{\mathrm{k}}
\end{array}\right]
$$


2. Preferences of all decision makers are averaged according to Eq. (2) and new pairwise comparison matrix is obtained as Eq. (3):

$$
\begin{aligned}
\widetilde{\mathrm{a}}_{\mathrm{ij}} & =\frac{\sum_{\mathrm{k}=1}^{\mathrm{K}} \mathrm{a}_{\mathrm{ij}}^{\mathrm{k}}}{\mathrm{K}} \\
\widetilde{\mathrm{A}} & =\left[\begin{array}{cccc}
\widetilde{\mathrm{a}}_{11} & \widetilde{\mathrm{a}}_{12} & \ldots & \widetilde{\mathrm{a}}_{1 \mathrm{n}} \\
\widetilde{\mathrm{a}}_{21} & \widetilde{\mathrm{a}}_{22} & \ldots & \widetilde{\mathrm{a}}_{2 \mathrm{n}} \\
\ldots & \ldots & \ldots & \ldots \\
\widetilde{\mathrm{a}}_{\mathrm{m} 1} & \widetilde{\mathrm{a}}_{\mathrm{m} 2} & \ldots & \widetilde{\mathrm{a}}_{\mathrm{mn}}
\end{array}\right]
\end{aligned}
$$

3. Geometric mean of each criterion is calculated according to Eq. (4):

$$
\widetilde{\mathrm{z}}_{\mathrm{i}}=\left[\prod_{\mathrm{j}=1}^{\mathrm{n}} \widetilde{\mathrm{a}}_{\mathrm{ij}}\right]^{1 / \mathrm{n}}, \mathrm{i}=1,2, \ldots, \mathrm{m}
$$

4. The fuzzy weights of each criterion are obtained by finding vector summation of each , acquiring ( -1$)$ power of summation vector and replacing in an increasing order, and finally multiplying with reverse vector according to Eq. (5):

$$
\widetilde{\mathrm{w}}_{\mathrm{i}}=\widetilde{\mathrm{z}}_{\mathrm{i}} \otimes\left(\widetilde{\mathrm{z}}_{1} \oplus \widetilde{\mathrm{z}}_{2} \oplus \ldots \oplus \widetilde{\mathrm{z}}_{\mathrm{n}}\right)^{-1}=\left(\mathrm{l}_{\mathrm{i}}, \mathrm{m}_{\mathrm{i}}, \mathrm{u}_{\mathrm{i}}\right)
$$

5. Fuzzy weights composed of fuzzy triangular numbers are transformed into crisp one by using Center of Area defuzzification techniques shown in Eq. (6):

$$
\mathrm{S}_{\mathrm{i}}=\frac{1_{\mathrm{i}}+\mathrm{m}_{\mathrm{i}}+\mathrm{u}_{\mathrm{i}}}{3}
$$

6. After obtaining crisp weights normalization process is implemented such as Eq. (7): 


$$
\mathrm{T}_{\mathrm{i}}=\frac{\mathrm{S}_{\mathrm{i}}}{\sum_{\mathrm{i}=1}^{\mathrm{m}} \mathrm{S}_{\mathrm{i}}}
$$

Hwang and Yoon (1981) assert TOPSIS for analyzing MCDM problems. Basis of this technique is to choose alternative having the shortest euclidean distance from positive ideal solution (PIS) which maximizes benefit and minimizes cost, and the farthest distance from negative ideal solution (NIS) which maximizes cost and minimizes benefit (Behzadian, Otaghsara,Yazdani,Ignatius 2012). TOPSIS assumes that each criterion has monotonically increasing or decreasing utility (Pohekar, Ramachandran 2004). This technique aims to maximize or minimize each criterion and pairwise comparisons are abstained. In addition to that it does not include complex algorithms and mathematical models, easy to use, requires less input parameters and produces easily understandable outputs. On the other hand it is difficult to weight attributes and keep consistent judgments in case of additional attributes (Velasquez, Hester 2013). Structure of TOPSIS are revealed as follows (Tsaur 2011):

1. Forming decision matrix $\left(X=\left(x_{i j}\right)_{n x m}\right)$ for ranking the alternatives.

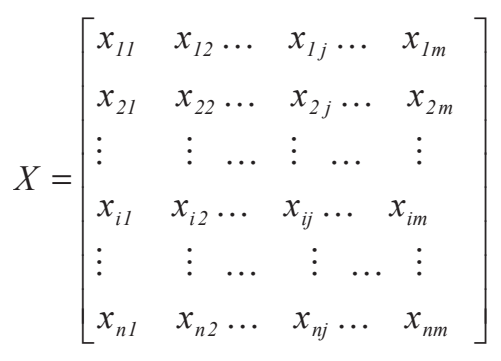

2. Normalizing decision matrix by

$$
r_{i j}=\frac{w_{i j}}{\sqrt{\sum_{i=1}^{m} w_{i j}^{2}}} i=1,2, \ldots, n \quad j=1,2, \ldots, m
$$

3. Weighting normalized decision matrix by multiplying normalized decision matrix and its' weights. 
$v_{i j}=r_{i j} \cdot w_{j} \quad i=1,2, \ldots, n \quad j=1,2, \ldots, m$

4. Determining positive and negative ideal solution as follows :

$$
\begin{aligned}
& P I S=A^{*}=\left\{v_{1}^{*}, v_{2}^{*}, \ldots, v_{m}^{*}\right\}=\left\{\left(\max _{i} v_{i j} \mid j \in \Omega_{b}\right),\left(\min _{i} v_{i j} \mid j \in \Omega_{c}\right)\right\} \\
& N I S=A^{-}=\left\{v_{1}^{-}, v_{2}^{-}, \ldots, v_{m}^{-}\right\}=\left\{\left(\min _{i} v_{i j} \mid j \in \Omega_{b}\right),\left(\max _{i} v_{i j} \mid j \in \Omega_{c}\right)\right\}
\end{aligned}
$$

5. Calculating euclidean distance of alternatives from positive and negative ideal solution as follows:

$$
\begin{aligned}
& d_{i}^{*}=\sqrt{\sum_{j=1}^{m}\left(v_{i j}-v_{j}^{*}\right)^{2}} \quad i=1,2, \ldots, n \\
& d_{i}^{-}=\sqrt{\sum_{j=1}^{m}\left(v_{i j}-v_{j}^{-}\right)^{2}} \quad i=1,2, \ldots, n
\end{aligned}
$$

6. Calculating relative closeness $\left(\mathrm{RC}_{\mathrm{i}}\right)$ of each alternative to ideal solution as below:

$$
R C_{i}=\frac{d_{i}^{-}}{d_{i}^{-}+d_{i}^{*}} \quad i=1,2, \ldots, n \quad R C_{i} \in[0,1]
$$

7. Ranking alternatives according to their $R C_{i}$ values in descending order from 1 to 0 and choosing the highest one.

VIKOR developed by Opricovic (1998), is a MCDM based on creating compromised solution by taking alternatives and criteria into the consideration. Method is oriented for selecting and ranking alternatives in case of conflicting criteria (Büyüközkan, Ruan 2008). Compromised solution is the closest to ideal one. In other words VIKOR based on measure of closeness to ideal solution is multi criteria decision ranking index (Opricovic, Tzeng 2004). In order to obtain solution, closest to ideal one, multi criteria ranking index is generated for alternatives and then compared between the values of closeness to ideal so- 
lution (Opricovic, Tzeng 2007). Decision making process of VIKOR starts with problem definition. By this way aim of problem, alternatives, criteria and sub criteria (if needed) that will be evaluated are determined. Alternatives are selected, ranked and compared by utilizing cost or benefit based criteria. In evaluation process all alternatives get related criteria scores. VIKOR method can be used for solving MCDM problems if following conditions are satisfied: a) Compromised solution should be accepted in order to overcome conflict. b) Decision maker is willing to accept the closest solution to ideal one. c) A linear relationship between benefit and each criteria function for decision maker. d) Alternatives should be evaluated in terms of each criteria. e) Preferences of decision makers' are expressed by weights. f) Decision makers are responsible for approving the final solution (Ertuğrul, Karakaşoğlu 2008).

Steps of VIKOR method can be summarized as below:

a) Best $\left(f_{a}^{*}\right)$ and the worst $\left(f_{a}^{-}\right)$values for each evaluation criteria are identified. If evaluation criteria $(b=1,2, \ldots, n)$ is based on benefit;

$$
\mathrm{f}_{\mathrm{b}}^{*}=\max _{\mathrm{a}} \mathrm{x}_{\mathrm{ab}} \quad \mathrm{f}_{\mathrm{b}}^{-}=\min _{\mathrm{a}} \mathrm{x}_{\mathrm{ab}}
$$

If evaluation criteria $(b=1,2, \ldots, n)$ is based on cost;

$$
\mathrm{f}_{\mathrm{b}}^{*}=\min _{\mathrm{a}} \mathrm{x}_{\mathrm{ab}} \quad \mathrm{f}_{\mathrm{b}}^{-}=\max _{\mathrm{a}} \mathrm{x}_{\mathrm{ab}}
$$

b) In order to make comparisons normalization process is used and by this way normalization matrix is obtained. In normalization process decision matrix $(\mathrm{X})$ composed of $\mathrm{k}$ criteria and $\mathrm{l}$ alternatives transformed into normalization matrix (S) with same dimensions. Before normalization decision matrix $(\mathrm{X})$ consisted of elements $\left(\mathrm{x}_{\mathrm{kl}}\right)$ is seen as below;

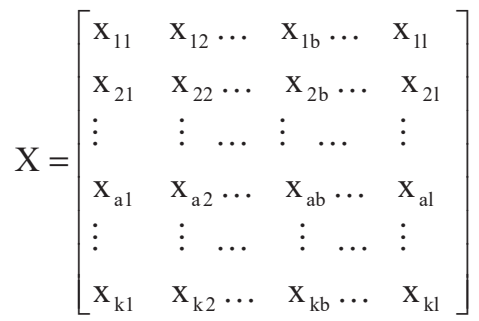


After normalization process normalization matrix (S) consisted of elements $\left(\mathrm{S}_{\mathrm{kl}}\right)$ is seen as below;

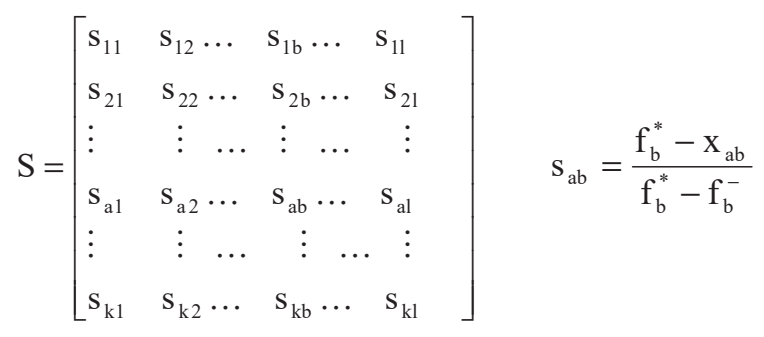

c) Weighted normalized decision matrix (T) is obtained by multiplying criteria weights $\left(\mathrm{W}_{\mathrm{b}}\right)$ and normalized decision matrix elements $\left(\mathrm{S}_{\mathrm{ab}}\right)$.

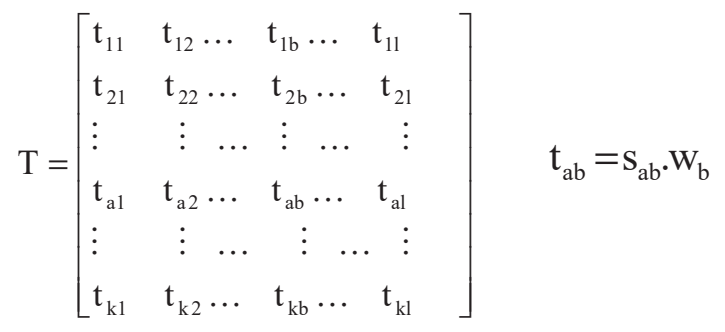

d) Values of $\mathrm{S}_{\mathrm{a}}$ (mean group score) and $\mathrm{R}_{\mathrm{a}}$ (worst group score) are calculated for each alternative.

$$
\mathrm{S}_{\mathrm{a}}=\sum_{\mathrm{b}=1}^{1} \mathrm{w}_{\mathrm{b}} \frac{\mathrm{f}_{\mathrm{b}}^{*}-\mathrm{x}_{\mathrm{ab}}}{\mathrm{f}_{\mathrm{b}}^{*}-\mathrm{f}_{\mathrm{b}}^{-}} \quad \mathrm{R}_{\mathrm{a}}=\max _{\mathrm{b}}\left[\mathrm{w}_{\mathrm{b}} \frac{\mathrm{f}_{\mathrm{b}}^{*}-\mathrm{x}_{\mathrm{ab}}}{\mathrm{f}_{\mathrm{b}}^{*}-\mathrm{f}_{\mathrm{b}}^{-}}\right]
$$

e) Value of $Q_{a}$ is calculated for each alternative. Values of $S^{*}, S^{-}, R^{*}, R^{-}$are used to acquire the value of $\mathrm{Q}_{\mathrm{a}}$. Additionally $\mathrm{y}$ parameter showing maximum group benefit states the weight of alternative providing maximum group benefit. On the contrary (1-y) parameter refers to weight of minimum regret. Compromise is reached by majority $(y>0.5)$, consensus $(y=0.5)$ or veto $(\mathrm{y}<0.5)$ (Opricovic, Tzeng 2007). Generally $\mathrm{y}=0.5$ is used (Lixin, Ying, Zhiguang 2008). 


$$
\begin{aligned}
& \mathrm{S}^{*}=\min _{\mathrm{a}} \mathrm{S}_{\mathrm{a}} \\
& \mathrm{S}^{-}=\max _{\mathrm{a}} \mathrm{S}_{\mathrm{a}} \quad \mathrm{Q}_{\mathrm{a}}=\mathrm{y} \frac{\mathrm{S}_{\mathrm{a}}-\mathrm{S}^{*}}{\mathrm{~S}^{-}-\mathrm{S}^{*}}+(1-\mathrm{y}) \frac{\mathrm{R}_{\mathrm{a}}-\mathrm{R}^{*}}{\mathrm{R}^{-}-\mathrm{R}^{*}} \\
& \mathrm{R}^{*}=\min _{\mathrm{a}} \mathrm{R}_{\mathrm{a}} \\
& \mathrm{R}^{-}=\max _{\mathrm{a}} \mathrm{R}_{\mathrm{a}}
\end{aligned}
$$

f) Values of $S_{a}, R_{a}$ and $Q_{a}$ are ranked from lower to higher and alternative having minimum $Q_{a}$ value is controlled by two conditions whether ranking is accurate. These conditions are named acceptable advantage and acceptable stability.

Acceptable advantage condition: According to $Q_{a}$ values first $\left(Q\left(C_{1}\right)\right)$ and second alternative $\left(Q\left(C_{2}\right)\right)$ satisfied significant difference. Calculated threshold value (DQ) depend on alternative number. If the number of alternative is lower than 4 the value of DQ equals to 0.25 (Chen, Wang 2009).

$$
\mathrm{Q}\left(\mathrm{C}_{1}\right)-\mathrm{Q}\left(\mathrm{C}_{2}\right) \geq \mathrm{DQ} \quad \mathrm{DQ}=\frac{1}{\mathrm{k}-1}
$$

Acceptable stability condition: According to $Q_{a}$ values first alternative $\left(\mathrm{Q}\left(\mathrm{C}_{1}\right)\right.$ ) should get the best score at least one for values of $\mathrm{S}$ and $\mathrm{R}$. Unless these two conditions are not satisfied compromised solution set is formed by two ways:

1. If second condition is not satisfied first and second alternatives are accepted as compromised solution.

2. If first condition is not satisfied $\mathrm{C}_{1}, \mathrm{C}_{2}, \ldots, \mathrm{C}_{\mathrm{k}}$ alternatives are contained in compromised solution set according to $Q\left(C_{k)}-Q\left(C_{1}\right) \geq D Q\right.$ (Opricovic, Tzeng 2004).

ELECTRE, which was asserted by Roy (1965), is based on outranking relations between alternatives in terms of criteria by using satisfaction and dissatisfaction measures namely concordance and discordance indexes. Decision makers can select the best alternative via incorporating and weighting criteria in this method (Sevkli 2010). In order to solve decision problems more than 
two criteria ELECTRE methods can be preferred to other ones if at least one of these conditions is satisfied: a) Performances of criteria are expressed stated in different units and decision maker does not want to use complex and difficult common scale. b) The problem does not tolerate a compensation effect. c) If there is requirement to use indifference and preference thresholds such that sum of small differences is decisive apart from insignificant small differences. d) If alternatives are weak interval or any order scale in which it is difficult to compare differences (Ishizaka, Nemery 2013). ELECTRE allows decision makers to avoid compensation and between criteria and any normalization process that can distort original data, also uncertain conditions are being considered. On the other hand these methods require difficult technical parameters which are not easily understandable (Ishizaka, Nemery 2013).

Different versions of ELECTRE (II, III, IV etc.) can be used according to the decision problem type. Steps of ELECTRE can be summarized as follows (Yoon, Hwang 1995):

1. Forming decision matrix $\left(A=\left(a_{i j}\right)_{m x n}\right)$ for $m(i=1,2, \ldots, m)$ alternatives and $n(j=1,2, \ldots, n)$ criteria.

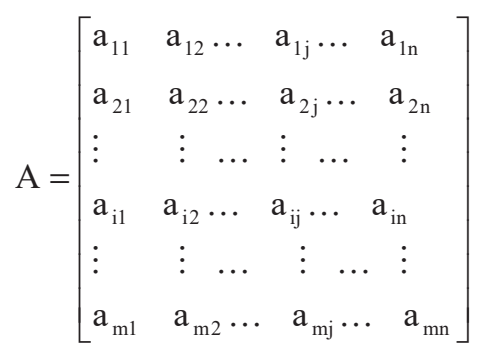

2. Forming normalized decision matrix $\left(X=\left(x_{i j}\right)_{m x n}\right)$ for $m(i=1,2, \ldots, m)$ alternatives and $n(j=1,2, \ldots, n)$ criteria.

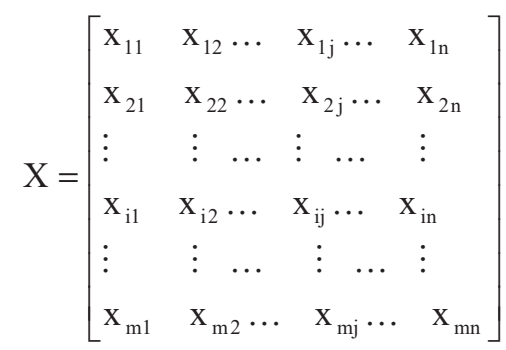




$$
\begin{aligned}
& \mathrm{x}_{\mathrm{ij}}=\frac{\mathrm{a}_{\mathrm{ij}}}{\sqrt{\sum_{\mathrm{i}=1}^{\mathrm{m}} \mathrm{a}_{\mathrm{ij}}^{2}}} \text { for maximization objective } \\
& \mathrm{x}_{\mathrm{ij}}=\frac{\frac{1}{\mathrm{a}_{\mathrm{ij}}}}{\sqrt{\sum_{\mathrm{i}=1}^{\mathrm{m}}\left(\frac{1}{\mathrm{a}_{\mathrm{ij}}}\right)^{2}}} \text { for minimization objective }
\end{aligned}
$$

3. Calculating weighted normalized decision matrix $\left(V=\left(v_{i j}\right)_{m \times n}\right)$ via multiplying weight of criterion $\left(\mathrm{w}_{\mathrm{j}}\right)$ by elements of normalized decision matrix $\left(\mathrm{x}_{\mathrm{ij}}\right)$.

$$
\mathrm{v}_{\mathrm{ij}}=\mathrm{w}_{\mathrm{j}} \cdot \mathrm{x}_{\mathrm{ij}}
$$

4. Determining concordance and discordance sets for each pair of alternatives $A_{p}$ and $A_{p}(p, q=1,2, \ldots, m$ and $p \neq q)$ in case of searched alternatives not being the best one for all criteria. If alternative $A_{p}$ is preferred to alternative $A_{q}$ for all criteria concordance set $(C(p, q))$, collection of criteria where $A_{p}$ is better than or equal to $A_{q}$, is formed as below:

$$
\mathrm{C}(\mathrm{p}, \mathrm{q})=\left\{\mathrm{j} \mid \mathrm{v}_{\mathrm{pj}} \geq \mathrm{v}_{\mathrm{qj}}\right\}
$$

On the other hand if alternative $A_{p}$ is worse than $A_{q}$ for all criteria discordance set $(D(p, q))$, collection $A_{p}$ of criteria for which is worse than $A_{q}$, is formed as below:

$$
\mathrm{D}(\mathrm{p}, \mathrm{q})=\left\{\mathrm{j} \mid \mathrm{v}_{\mathrm{pj}}<\mathrm{v}_{\mathrm{qj}}\right\}
$$

According to the above formulations $\mathrm{V}_{\mathrm{pj}}$ is defined as the weighted normalized rating of alternative $A_{p}$ with regard to $j$ th criterion and $V_{q j}$ is defined as the weighted normalized rating of alternative $A_{q}$ with respect to jth criterion.

5. Calculating the concordance $\left(\mathrm{C}_{\mathrm{p}, \mathrm{q}}\right)$ and discordance $\left(\mathrm{D}_{\mathrm{p}, \mathrm{q}}\right)$ indexes shown as follows:

$$
\mathrm{C}_{\mathrm{pq}}=\sum_{\mathrm{j}^{*}} \mathrm{~W}_{\mathrm{j}^{*}}
$$


According to Eq. (31) criteria involved in concordance set $(\mathrm{C}(\mathrm{p}, \mathrm{q}))$ are represented by $\mathrm{j}^{*}$.

$$
\mathrm{D}_{\mathrm{pq}}=\frac{\sum_{\mathrm{j}^{+}}\left|\mathrm{v}_{\mathrm{pj}^{+}}-\mathrm{v}_{\mathrm{qj}^{+}}\right|}{\sum_{\mathrm{j}}\left|\mathrm{v}_{\mathrm{pj}}-\mathrm{v}_{\mathrm{qj}^{\mathrm{j}}}\right|}
$$

According to Eq. (32) criteria involved in discordance set (D(p,q)) are represented by j ${ }^{+}$

6. Relationships between alternatives are outranked by computing the averages of $\mathrm{C}_{\mathrm{pg}}$ and $\mathrm{D}_{\mathrm{pg}}$ that is represented by $\overline{\mathrm{C}}$ and $\overline{\mathrm{D}}$ respectively. According to this method alternative of $A_{p}$ outrank the alternative of $A_{q}$ if and only $\mathrm{C}_{\mathrm{pq}} \geq \overline{\mathrm{C}}$ and $\mathrm{D}_{\mathrm{pq}} \leq \overline{\mathrm{D}}$ conditions are satisfied. By the way it should be control whether alternatives selected via this method comprise kernel.

7. Net concordance $\left(C_{p}\right)$ and discordance $\left(D_{p}\right)$ indexes, that are shown as below, are calculated. The ultimate ranking is obtained according to ordering $\mathrm{C}_{\mathrm{p}}$ values from higher to lower and $\mathrm{D}_{\mathrm{p}}$ values from lower to higher.

$$
\begin{array}{ll}
\mathrm{C}_{\mathrm{p}}=\sum_{\mathrm{k}=1}^{\mathrm{m}} \mathrm{C}_{\mathrm{pk}}-\sum_{\mathrm{k}=1}^{\mathrm{m}} \mathrm{C}_{\mathrm{kp}} & \mathrm{k} \neq \mathrm{p} \\
\mathrm{D}_{\mathrm{p}}=\sum_{\mathrm{k}=1}^{\mathrm{m}} \mathrm{D}_{\mathrm{pk}}-\sum_{\mathrm{k}=1}^{\mathrm{m}} \mathrm{D}_{\mathrm{kp}} & \mathrm{k} \neq \mathrm{p}
\end{array}
$$

\section{RESULTS OF RESEARCH}

Purpose of this study is to assess the properties of different MCDM methods and compare the results of them in terms of evaluating the performance of 21 food firms listed in BIST by the help of financial ratios composing 5 year data set. For this purpose firstly financial ratios of each food firm listed in BIST are calculated. Eight financial ratios namely currency, acid test, cash, leverage, asset turnover, net profit/total assets, net profit/capital and net profit/net sales are considered. Then a survey evaluating the financial ratios was designed and applied for determining the weights of criteria and sub criteria. Survey was based 
on Saaty's 9 point scale in order to weigh criteria and sub-criteria by pairwise comparisons in multilevel hierarchical structures. While defining the criteria and sub criteria, first of all, researchers made a depth literature review in order to develop the draft of the scale. 21 food companies listed in BIST are taken into the consideration as alternatives.

Content validity is ensured by consulting to the experts' opinion (especially academicians' from finance field). After these procedures have been completed, data collection process started. Participants were selected from financial experts operated in universities, public and private sector. Participants were asked to compare four main criteria with respect to goal and all sub criteria within each main criteria on a pair-wise basis to determine their relative importance. As a result, 18 complete surveys were collected and analyzed. Weights of the criteria and sub criteria were acquired from the survey by using Buckley's Column Geometric Mean approach, one of the fuzzy ranking methods.

According to the results of Buckley's Column Geometric Mean approach weights of ratios are given in Table 2. For all comparisons including criteria and sub criteria consistency ratios are under the 0.1 threshold level so comparisons made were consistent. After the weights of criteria and sub criteria are determined, criteria related values of 21 food firms listed in BIST within the period of 2011-2014 are obtained from firms' websites. For ranking firms via TOPSIS, VIKOR and ELECTRE methodology EXCEL 2013 software is used.

Table 2. Weights of ratios

\begin{tabular}{|l|c|}
\hline \hline \multicolumn{1}{|c|}{ Ratios } & Weights \\
\hline Currency Ratio & 0.215436 \\
\hline Acid Test Ratio & 0.178542 \\
\hline Cash Ratio & 0.077954 \\
\hline Leverage Ratio & 0.270593 \\
\hline Asset Turnover Ratio & 0.136721 \\
\hline Net Profit / Total Assets & 0.059624 \\
\hline Net Profit / Capital & 0.04073 \\
\hline Net Profit / Net Sales & 0.020401 \\
\hline \hline
\end{tabular}

S o u r c e : own study. 
According to the importance level of financial ratios leverage ratio was found as the most important criteria having the value of 0.270593 . On the other hand ratio of net profit/net sales was obtained as the least important one having the value of 0.020401 . values of each alternative and their rankings within the period of 2011-2014 are obtained via TOPSIS methodology and shown in Table 3.

Table 3. $R C_{i}$ values and rankings of food firms according to descending order

\begin{tabular}{|c|c|c|c|c|c|c|c|c|}
\hline \multirow[b]{2}{*}{ Firms } & \multicolumn{2}{|l|}{2011} & \multicolumn{2}{|l|}{2012} & \multicolumn{2}{|l|}{2013} & \multicolumn{2}{|c|}{2014} \\
\hline & $R C_{i}$ & Rank & $R C_{i}$ & Rank & $R C_{i}$ & Rank & $R C_{i}$ & Rank \\
\hline KERVT & 0.50989 & 16 & 0.507408 & 18 & 0.379014 & 19 & 0.440693 & 18 \\
\hline OYLUM & 0.534831 & 12 & 0.559625 & 7 & 0.452843 & 14 & 0.501208 & 14 \\
\hline ETILR & 0.605787 & 4 & 0.610882 & 4 & 0.541313 & 2 & 0.5427 & 8 \\
\hline TACTR & 0.537611 & 10 & 0.519595 & 15 & 0.447172 & 15 & 0.501864 & 13 \\
\hline TATGD & 0.550522 & 7 & 0.545988 & 11 & 0.474083 & 9 & 0.565973 & 5 \\
\hline TKURU & 0.491717 & 20 & 0.818974 & 1 & 0.70315 & 1 & 0.623132 & 3 \\
\hline TUKAS & 0.502964 & 18 & 0.662827 & 2 & 0.416609 & 18 & 0.500321 & 15 \\
\hline ULKER & 0.538916 & 9 & 0.621493 & 3 & 0.514934 & 4 & 0.729944 & 1 \\
\hline VANGD & 0.54707 & 8 & 0.534708 & 12 & 0.493462 & 5 & 0.563026 & 6 \\
\hline YAPRK & 0.61134 & 3 & 0.577484 & 5 & 0.493337 & 6 & 0.536027 & 9 \\
\hline DARDL & 0.13309 & 21 & 0.164859 & 21 & 0.299255 & 20 & 0.23304 & 21 \\
\hline AVOD & 0.576703 & 6 & 0.497203 & 19 & 0.470988 & 11 & 0.527845 & 10 \\
\hline PENGD & 0.5056 & 17 & 0.525511 & 14 & 0.456942 & 12 & 0.506234 & 12 \\
\hline MRTGG & 0.49905 & 19 & 0.568888 & 6 & 0.45329 & 13 & 0.394608 & 20 \\
\hline MANGO & 0.53469 & 13 & 0.518172 & 16 & 0.42858 & 17 & 0.412764 & 19 \\
\hline MERKO & 0.576858 & 5 & 0.558215 & 8 & 0.444587 & 16 & 0.55126 & 7 \\
\hline ALYAG & 0.520311 & 15 & 0.546026 & 10 & 0.484433 & 7 & 0.521477 & 11 \\
\hline ARTOG & 0.613169 & 2 & 0.466867 & 20 & 0.515367 & 3 & 0.595072 & 4 \\
\hline FRIGO & 0.521809 & 14 & 0.516894 & 17 & 0.47542 & 8 & 0.488383 & 16 \\
\hline KRSAN & 0.816341 & 1 & 0.525812 & 13 & 0.473192 & 10 & 0.465774 & 17 \\
\hline KENT & 0.536358 & 11 & 0.555004 & 9 & 0.241906 & 21 & 0.623391 & 2 \\
\hline
\end{tabular}


According to the firms' ranking related to $\mathrm{RC}_{\mathrm{i}}$ values KRSAN, ARTOG and YAPRK place top three position for 2011 respectively. On the contrary DARDL, TKURU and MRTGG place the last three position for 2011 respectively. While TKURU, TUKAS and ULKER perform as the top three food firms, DARDL, ARTOG and AVOD place the last three position for 2012. Top three food firms in the context of financial performance are ranked as TKURU, ETILR and ARTOG in 2013. This condition is valid for KENT, DARDL and KERVT as the last three food firms for 2013. Lastly while ULKER, KENT and TKURU perform as the top three food firms, DARDL, MRTGG and MANGO place the last three position for 2014. Some inconsistent outputs can be seen after applying the TOPSIS method. Firstly while TKURU places the 20th position in 2011, it places the top three position in the range of 2012-2014. Similarly ARTOG places the top four position apart from the year of 2012. Other food firms suffered from the inconsistent results can be stated as KRSAN, TUKAS, MERKO and KENT respectively.

By applying VIKOR methodology in order to obtain values of each alternative consensus condition is considered and thus parameter (q) showing maximum group benefit is used as 0.5 . Ranking of food firms in ascending order after acquiring values within the period of 2011-2014 are shown in Table 4.

Table 4. $Q$ a values ( $q=0.5$ ) and rankings of food firms according to ascending order

\begin{tabular}{|c|c|c|c|c|c|c|c|c|}
\hline \multirow[b]{2}{*}{ Firms } & \multicolumn{2}{|c|}{2011} & \multicolumn{2}{|c|}{2012} & \multicolumn{2}{|c|}{2013} & \multicolumn{2}{|c|}{2014} \\
\hline & $Q_{a}$ & Rank & $Q_{a}$ & Rank & $Q_{a}$ & Rank & $Q_{a}$ & Rank \\
\hline KERVT & 0.531843 & 17 & 0.465892 & 14 & 0.71143 & 20 & 0.56407 & 17 \\
\hline OYLUM & 0.522189 & 14 & 0.418068 & 10 & 0.607527 & 17 & 0.513941 & 16 \\
\hline ETILR & 0.294855 & 2 & 0.220251 & 3 & 0.267991 & 2 & 0.353355 & 7 \\
\hline TACTR & 0.489162 & 12 & 0.566464 & 20 & 0.671333 & 18 & 0.501523 & 15 \\
\hline TATGD & 0.392574 & 6 & 0.417605 & 9 & 0.458707 & 7 & 0.293031 & 5 \\
\hline TKURU & 0.629968 & 20 & 0 & 1 & 0 & 1 & 0.134067 & 2 \\
\hline TUKAS & 0.613671 & 19 & 0.242336 & 4 & 0.547523 & 13 & 0.46239 & 12 \\
\hline ULKER & 0.460664 & 8 & 0.192898 & 2 & 0.427773 & 5 & 0 & 1 \\
\hline VANGD & 0.468493 & 10 & 0.51642 & 17 & 0.468869 & 9 & 0.29777 & 6 \\
\hline YAPRK & 0.332044 & 4 & 0.400186 & 8 & 0.442589 & 6 & 0.424966 & 10 \\
\hline DARDL & 1 & 21 & 1 & 21 & 1 & 21 & 1 & 21 \\
\hline AVOD & 0.331932 & 3 & 0.529098 & 19 & 0.485923 & 11 & 0.415338 & 9 \\
\hline
\end{tabular}




\begin{tabular}{|l|c|c|c|c|c|c|c|c|}
\hline \hline \multirow{2}{*}{ Firms } & \multicolumn{2}{|c|}{2011} & \multicolumn{2}{c|}{2012} & \multicolumn{2}{c}{2013} & \multicolumn{2}{c|}{2014} \\
\cline { 2 - 9 } & $Q_{a}$ & Rank & $Q_{a}$ & Rank & $Q_{a}$ & Rank & $Q_{a}$ & Rank \\
\hline \hline PENGD & 0.556397 & 18 & 0.491269 & 15 & 0.505888 & 12 & 0.456352 & 11 \\
\hline MRTGG & 0.384604 & 5 & 0.396928 & 7 & 0.581811 & 15 & 0.656866 & 19 \\
\hline MANGO & 0.464058 & 9 & 0.464351 & 13 & 0.582109 & 16 & 0.644862 & 18 \\
\hline MERKO & 0.442859 & 7 & 0.463016 & 12 & 0.576545 & 14 & 0.359542 & 8 \\
\hline ALYAG & 0.508062 & 13 & 0.429859 & 11 & 0.484551 & 10 & 0.480045 & 13 \\
\hline ARTOG & 0.529193 & 15 & 0.31 & 5 & 0.339673 & 3 & 0.228217 & 4 \\
\hline FRIGO & 0.5304 & 16 & 0.509877 & 16 & 0.419432 & 4 & 0.490496 & 14 \\
\hline KRSAN & 0 & 1 & 0.519108 & 18 & 0.461385 & 8 & 0.664285 & 20 \\
\hline KENT & 0.481138 & 11 & 0.382463 & 6 & 0.693706 & 19 & 0.192878 & 3 \\
\hline \hline
\end{tabular}

S o u r c e : own study.

Acceptable advantage and acceptable stability conditions are satisfied for four years period (2011-2014). According to the acceptable advantage condition difference between first and second alternative having $Q_{a}$ values are greater than or equal the threshold value ( $D Q=0.05$ for $\mathrm{k}=21)$. However according to $Q_{a}$ values first alternative get the best score for values of both $S_{a}$ and $R_{a^{\prime}}$, thus acceptable stability condition is satisfied.

In terms of firms' ranking related to $Q_{a}$ values KRSAN, ETILR and AVOD place the top three position for 2011 respectively. On the contrary DARDL, TKURU and TUKAS place the last three position for 2011 respectively. While TKURU, ULKER and ETILR perform as the top three food firms , DARDL, TACTR and AVOD place the last three position for 2012. Top three food firms in the context of financial performance are ranked as TKURU, ETILR and ARTOG in 2013. This condition is valid for DARDL, KERVT and KENT as the last three food firms for 2013. Lastly while ULKER, TKURU and KENT perform as the top three food firms, DARDL, KRSAN and MRTGG place the last three position for 2014. AVOD, TKURU, TUKAS, ARTOG, KRSAN and KENT are suffered from inconsistent results in the range of 2011-2014 after applying the VIKOR method. $\mathrm{C}_{\mathrm{p}}$ values of each alternative and their rankings within the range of 2011-2014 are obtained via ELECTRE methodology and shown in Table 5. 
- COMPARISON OF MULTI CRITERIA DECISION MAKING...

Table 5. values and rankings of food firms according to descending order

\begin{tabular}{|c|c|c|c|c|c|c|c|c|}
\hline \multirow{2}{*}{ Firms } & \multicolumn{2}{|c|}{2011} & \multicolumn{2}{|c|}{2012} & \multicolumn{2}{|c|}{2013} & \multicolumn{2}{|c|}{2014} \\
\hline & & Rank & & Rank & & Rank & & Rank \\
\hline KERVT & -5.05132 & 16 & -3.74191 & 14 & -9.79619 & 19 & -8.49069 & 18 \\
\hline OYLUM & 4.066299 & 6 & 2.892397 & 9 & -6.53089 & 17 & -3.76751 & 15 \\
\hline ETILR & 9.312276 & 3 & 8.829443 & 3 & 12.0526 & 2 & 6.23837 & 6 \\
\hline TACTR & 2.833143 & 10 & -9.21342 & 20 & -7.81541 & 18 & -0.47822 & 12 \\
\hline TATGD & 3.612507 & 8 & -1.30122 & 12 & 4.990307 & 8 & 5.991833 & 7 \\
\hline TKURU & -11.9987 & 20 & 11.41063 & 2 & 8.840116 & 3 & 5.630924 & 8 \\
\hline TUKAS & -9.52866 & 18 & 0.739631 & 11 & -5.77915 & 16 & -2.30874 & 14 \\
\hline ULKER & 3.275375 & 9 & 15.25167 & 1 & 6.124375 & 5 & 6.323224 & 5 \\
\hline VANGD & 1.500985 & 11 & -3.46261 & 13 & 5.315509 & 7 & 8.387681 & 3 \\
\hline YAPRK & 9.50529 & 2 & 6.377541 & 4 & 8.801153 & 4 & 6.575883 & 4 \\
\hline DARDL & -12.0556 & 21 & -12.3511 & 21 & -10.2635 & 20 & -11.9765 & 19 \\
\hline AVOD & 10.02192 & 1 & -7.41517 & 18 & 0.272479 & 11 & 4.912043 & 9 \\
\hline PENGD & -9.87913 & 19 & -7.25223 & 17 & -2.96534 & 12 & -0.74082 & 13 \\
\hline MRTGG & -1.17844 & 14 & 4.135935 & 7 & -3.23204 & 13 & -15.571 & 21 \\
\hline MANGO & 4.783295 & 5 & -5.55873 & 16 & -11.3389 & 21 & -15.2416 & 20 \\
\hline MERKO & 4.983163 & 4 & 4.181412 & 6 & -5.49547 & 15 & 3.600398 & 10 \\
\hline ALYAG & -5.26583 & 17 & 2.052266 & 10 & 5.73018 & 6 & 1.877797 & 11 \\
\hline ARTOG & -0.05753 & 13 & 4.457873 & 5 & 12.18496 & 1 & 8.963694 & 2 \\
\hline FRIGO & -3.20064 & 15 & -8.07618 & 19 & 1.343427 & 10 & -4.0936 & 16 \\
\hline KRSAN & 3.704686 & 7 & -5.045 & 15 & 1.376178 & 9 & -8.17546 & 17 \\
\hline KENT & 0.616886 & 12 & 3.088766 & 8 & -3.81432 & 14 & 12.34223 & 1 \\
\hline
\end{tabular}

S o u r c e : own study.

In terms of firms' ranking related to $\mathrm{C}_{\mathrm{p}}$ values AVOD, YAPRK and ETILR place the top three position for 2011 respectively. On the contrary DARDL, TKURU and PENGD place the last three position for 2011 respectively. While ULKER, TKURU and ETILR perform as the top three food firms, DARDL, TACTR and FRIGO place the last three position for 2012. Top three food firms in the context of financial performance are ranked as ARTOG, ETILR and TKURU in 2013. This 
condition is valid for MANGO, DARDL and KERVT as the last three food firms for 2013. Lastly while KENT, ARTOG and VANGD perform as the top three food firms, MRTGG, MANGO and DARDL place the last three position for 2014. AVOD, TKURU, MRTGG, ARTOG, KRSAN and KENT are suffered from inconsistent results within the context of values. values of each alternative and their rankings within the range of 2011-2014 are obtained via ELECTRE methodology and shown in Table 6.

Table 6. values and rankings of food firms according to ascending order

\begin{tabular}{|c|c|c|c|c|c|c|c|c|}
\hline \multirow{2}{*}{ Firms } & \multicolumn{2}{|c|}{2011} & \multicolumn{2}{|c|}{2012} & \multicolumn{2}{|c|}{2013} & \multicolumn{2}{|c|}{2014} \\
\hline & & Rank & & Rank & & Rank & & Rank \\
\hline KERVT & 5.360736 & 15 & 3.98808 & 13 & 15.28188 & 21 & 11.06791 & 19 \\
\hline OYLUM & 2.567986 & 13 & 1.38132 & 11 & 9.524144 & 18 & 5.549148 & 15 \\
\hline ETILR & -12.0205 & 3 & -8.84642 & 3 & -16.2675 & 1 & -6.17664 & 7 \\
\hline TACTR & 3.148746 & 14 & 12.90877 & 21 & 10.95399 & 19 & 4.896926 & 13 \\
\hline TATGD & -0.87463 & 12 & 0.46839 & 10 & -3.09132 & 8 & -5.6017 & 8 \\
\hline TKURU & 17.76129 & 21 & -15.8779 & 2 & -15.5655 & 2 & -9.97883 & 5 \\
\hline TUKAS & 13.7527 & 20 & -8.21683 & 4 & 8.663544 & 17 & 5.547872 & 14 \\
\hline ULKER & -5.87499 & 7 & -16.9419 & 1 & -8.48023 & 5 & -13.2718 & 1 \\
\hline VANGD & -12.8804 & 2 & 5.598404 & 14 & -4.95088 & 6 & -12.71178 & 3 \\
\hline YAPRK & -10.4432 & 4 & -6.00319 & 7 & -10.6987 & 4 & -5.24372 & 9 \\
\hline DARDL & 13.05345 & 19 & 8.289244 & 16 & -4.05861 & 7 & 8.470648 & 17 \\
\hline AVOD & -7.35979 & 6 & 6.77209 & 15 & -1.01224 & 9 & -3.01106 & 10 \\
\hline PENGD & 13.0032 & 18 & 8.32757 & 17 & 6.5413 & 15 & 4.39811 & 12 \\
\hline MRTGG & -2.4648 & 9 & -5.44243 & 8 & 4.342252 & 14 & 17.82071 & 20 \\
\hline MANGO & -4.91216 & 8 & 10.00535 & 19 & 15.138124 & 20 & 18.450842 & 21 \\
\hline MERKO & -9.02815 & 5 & -7.44385 & 6 & 7.129846 & 16 & -8.13742 & 6 \\
\hline ALYAG & -1.88785 & 10 & 2.200656 & 12 & 2.620903 & 12 & -1.81698 & 11 \\
\hline ARTOG & 9.226474 & 17 & -7.88178 & 5 & -11.91262 & 3 & -12.18899 & 4 \\
\hline FRIGO & 7.19831 & 16 & 9.184832 & 18 & -0.426548 & 10 & 5.773014 & 16 \\
\hline KRSAN & -16.0763 & 1 & 12.14587 & 20 & 0.744134 & 11 & 9.126434 & 18 \\
\hline KENT & -1.25014 & 11 & -4.61621 & 9 & 3.064286 & 13 & -12.96266 & 2 \\
\hline
\end{tabular}

S o u r c e : own study. 
In terms of firms' ranking related to $\mathrm{D}_{\mathrm{p}}$ values KRSAN, VANGD and ETILR place the top three position for 2011 respectively. On the contrary TKURU, TUKAS and DARDL place the last three position for 2011 respectively. While ULKER, TKURU and ETILR perform as the top three food firms TACTR, KRSAN and MANGO place the last three position for 2012. Top three food firms in the context of financial performance are ranked as ETILR, TKURU and ARTOG in 2013. This condition is valid for KERVT, MANGO and TACTR as the last three food firms for 2013. Lastly while ULKER, KENT and VANGD perform as the top three food firms, MANGO, MRTGG and KERVT place the last three position for 2014. TUKAS, TKURU, MERKO, ARTOG, KRSAN, DARDL, VANGD and KENT are suffered from inconsistent results within the context of $\mathrm{D}_{\mathrm{p}}$ values.

According to the results of three methods while YAPRK and ETILR place the top five position, PENGD, TUKAS, TKURU and DARDL perform as the last five food firms in 2011. However, KRSAN perform the best financial performance and places the top position in 2011 with regard to $R C_{i}, \mathrm{Q}_{\mathrm{a}^{\prime}}$ and $\mathrm{D}_{\mathrm{p}}$ values. That is true for AVOD in the context of $C_{p}$ values. Apart from that while ARTOG places the top five position according to the values, it places the last five one considering $\mathrm{D}_{\mathrm{p}}$ values. TKURU, ULKER and ETILR place in the top five position for all ranking methods in 2012. But all ranking methods are not agree with firms placing in the last five position for 2012. While TKURU, ULKER, ARTOG and ETILR perform as the top five food firms in 2013, this condition is valid for KERVT placing as the last five food firms according to all ranking methods with regard to $R C_{i}, \mathrm{Q}_{\mathrm{a}}, \mathrm{C}_{\mathrm{p}}$ and $\mathrm{D}_{\mathrm{p}}$ values. Lastly common firms placing in the top five position for all ranking methods are stated as ULKER, KENT and ARTOG in 2014. MRTGG, MANGO, KERVT, DARDL and KRSAN are common firms placing in the last five position with respect to $R C_{i}, \mathrm{Q}_{\mathrm{a}}, \mathrm{C}_{\mathrm{p}}$ and $\mathrm{D}_{\mathrm{p}}$ values in 2014.

\section{RECOMMENDATIONS AND FUTURE RESEARCH}

In this study performances of twenty one food firms listed in BIST are analyzed in the context of different financial ratios and ranked via different MCDM methods namely TOPSIS, VIKOR and ELECTRE within the period of 2011-2014. For this purpose weights of financial ratios are obtained by using Buckley's Column Geometric Mean approach, one of the fuzzy ranking methods. There is not enough study based on comparing the performances of food firms listed in BIST via fuzzy ranking integrated MCDM methods. Ultimately all of MCDM 
methods which are based on weighted financial ratios give the similar ranking results by years. For further researches it is recommended to integrate the different weights and ranking approaches with respect to measuring performances of food firms listed in BIST. Additionally all of three methods can be used for ranking firms in other sectors according to financial performances.

\section{REFERENCES}

Altman, E.I. (1968). Financial Ratios, Discriminant Analysis And The Prediction of Corporate Bankruptcy. The Journal of Finance, 23(4), 589-609. http://dx.doi. org/10.1111/j.1540-6261.tb00843.x.

Behzadian, M., Otaghsara, S.K., Yazdani, M., \& Ignatius, J. (2012). A State of Art Survey of TOPSIS Applications, Expert Sytems with Applications, 39, 13051-13069. http:// dx.doi.org/10.1016/j.eswa.2012.05.056.

Bhushan, N., \& Rai, K. (2004). Strategic Decision Making Applying the Analytic Hierarchy Process, Springer. http://dx.doi.org/10.1007/b97668.

Buckley, J.J. (1985). Ranking alternatives using fuzzy numbers. Fuzzy Sets and Systems, 15(1), 21-31. http://dx.doi.org/10.1016/0165-0114(85)90013-2.

Bülbül, S., \& Köse, A. (2011). Türk Gıda Şirketlerinin Finansal Performansının Çok Amaçlı Karar Verme Yöntemleriyle Değerlendirilmesi, Atatürk Üniversitesi İỉBF Dergisi 10.Ekonometri ve İstatistik Sempozyumu Özel Sayısl, 71-97.

Büyüközkan, G., \& Ruan, D. (2008). Evaluation of Software Development Projects Using a Fuzzy Multi-Criteria Decision Approach. Mathematics and Computers in Simulation, 77, 464-475. http://dx.doi.org/10.1016/j.matcom.2007.11.015.

Chen, L.Y., \& Wang, T. (2009). Optimizing Partners' Choice in IS/IT Outsourcing Process: The Strategic Decision for Fuzzy VIKOR, International Journal of Production Economics, 120(1), 233-242. http://dx.doi.org/10.1016/j.ijpe.2008.07.022.

Chen, S.C., Hwang, C., \& Hwang, F. (1992). Fuzzy Multiple Attribute Decision Making: Methods and Applications, Springer- Verlag: New York. http://dx.doi.org/10.1007/978-3642-46768-4_5.

Dumanoğlu, S. (2010). İMKB'de İșlem Gören Çimento Şirketlerinin Mali Performansının TOPSIS Yöntemi İle Değerlendirilmesi, Marmara Üniversitesi İ̉BF Dergisi, 29(2), 323-339.

Ertuğrul, İ., \& Karakaşoğlu, N. (2008). Banka Şube Performanslarının VIKOR Yöntemi İle Değerlendirilmesi, Endüstri Mühendisliği Dergisi YA/EM 2008 Özel Sayısı, 20(1), 19-28.

Ertuğrul, İ., \& Karakașoğlu, N. (2009). Performance Evaluation of Turkish Cement Firms with Fuzzy Analytic Hierarchy Process and TOPSIS Methods, Expert Systems with Applications, 36, 702-715. http://dx.doi.org/10.1016/j.eswa.2007.10.014.

Feng, C.M., \& Wang, R.T. (2000). Performance Evaluation for Airlines Including the Consideration of Financial Ratios, Journal of Air Transport Management, 6(3), 133-142. http://dx.doi.org/10.1016/S0969-6997(00)00003-X. 
Huang, H.C., \& Ho, C.C. (2013). Applying the Fuzzy Analytic Hierarchy Process to Consumer Decision-Making Regarding Home Stays. International Journal of Advancements in Computing Technology, 5(4), 981-990. http://dx.doi.org/10.4156/ijact. vol5.issue4.119.

Ishizaka, A., \& Nemery, P. (2013). Multi Criteria Decision Analysis Methods and Software. John Wiley \& Sons. http://dx.doi.org/10.1002/9781118644898.

İç, Y., Tekin, M., Pamukoğlu, Z. \& Yıldırım, E. (2015) Kurumsal Firmalar İçin Bir Finansal Performans Karşılaştırma Modelinin Geliştirilmesi, Gazi Üniversitesi Mühendislik Mimarlık Fakültesi Dergisi, 30(1), 71-85. http://dx.doi.org/10.17341/gummfd.03450.

Jie, L.H., Meng, M.C., \& Cheong, C.W. (2006). Web Based Fuzzy Multicriteria Decision Making Tool. International Journal of The Computer, the Internet and Management, 14(2), 1-14.

Kahraman, C., Cebeci, U., \& Ulukan, Z. (2003). Multi-criteria supplier selection using fuzzy AHP. Logistics Information Management, 16(6), 382-394. http://dx.doi. org/10.1108/09576050310503367.

Kaptanoğlu, D., \& Özok, A.F. (2006). Akademik Performans Değerlendirmesi İçin Bir Bulanık Model. İTÜ Dergisi/d mühendislik, 5(1), 193-204.

Lixin, D., Ying, L., \& Zhiguang, Z. (2008). Selection of Logistics Service Provider Based on Analytic Network Process and VIKOR Algorithm, Networking, Sensing and Control, ICNSC 2008-IEEE International Conference Proceedings, 1207-1210.

Mahmoodzadeh, S., Shahrabi, J., Pariazar, M., \& Zaeri, S. (2007). Project Selection by Using Fuzzy AHP and TOPSIS Technique, International Journal of Social, Behavioral, Educational, Economic, Business and Industrial Engineering, 1(6), 270-275.

Opricovic, S., \& Tzeng, G.H. (2004). The Compromise Solution by MCDM Methods: A Comparative Analysis of VIKOR and TOPSIS, European Journal of Operational Research, 178(1), 445-455. http://dx.doi.org/10.1016/S0377-2217(03)00020-1.

Opricovic, S., \& Tzeng, G.H. (2007). Extended VIKOR Method in Comparison with Other Outranking Methods, European Journal of Operational Research, 178(2), 514-529. http://dx.doi.org/10.1016/j.ejor.2006.01.020.

Pohekar, S.D., \& Ramachandran, M. (2004). Application of multi criteria decision making to sustainable energy planning- A review, Renewable Sustainable Energy Reviews, 8, 365-381. http://dx.doi.org/10.1016/j.rser.2003.12.007.

Sevkli, M. (2010). An Application of the Fuzzy ELECTRE Method for Supplier Selection, International Journal of Production Research, 48(12), 3393-3405. http://dx.doi. org/10.1080/00207540902814355.

Tsaur, R.C. (2011). Decision Risk Analysis For an Interval TOPSIS Method, Applied Mathematics and Computation, 218, pp. 4295-4304. http://dx.doi.org/10.1016/j. amc.2011.10.001.

Uyguntürk, H., \& Korkmaz, T. (2012). Finansal Performansın TOPSIS Çok Kriterli Karar Verme Yöntemi İle Belirlenmesi: Ana Metal Sanayi İşletmeleri Üzerine Bir Uygulama, Eskişehir Osmangazi Üniversitesi İ̉BF Dergisi, 7(2), 95-115.

Velasquez, M., \& Hester, P.T. (2013). An Analysis of Multi-Criteria Decision Making Methods, International Journal of Operations Research, 10(2), 56-66. 
Wu, H.Y., Tzeng, G.H., \& Chen, Y.H. (2009). A fuzzy MCDM approach for evaluating banking performance based on Balanced Scorecard, Expert Systems with Applications, 36(6), 10135-10147. http://dx.doi.org/10.1016/j.eswa.2009.01.005.

Yoon, K.P., \& Hwang, C.L. (1995). Multiple Attribute Decision Making: An Introduction, Sage University Paper.

Yurdakul, M., \& İç, Y.T. (2003). Türk Otomotiv Firmalarının Performans Ölçümü ve Analizine Yönelik TOPSIS Yöntemini Kullanan Bir Ölçek Çalışma, Gazi Üniversitesi Mühendislik Mimarlık Fakültesi Dergisi, 18(1), 1-18.

Yüreğir, O.H., \& Nakıboğlu, G. (2007). Performans Ölçümü ve Ölçüm Sistemleri: Genel Bir Bakıș, Ç.Ü. Sosyal Bilimler Enstitüsü Dergisi, 16(2), 545-562. 